\title{
Institutional Strategies in the Ridesharing Economy: A Content Analysis Based on Uber's Example
}

\author{
Michaël Distelmans (D) and Ilse Scheerlinck* \\ Department of Business, Vrije Universiteit Brussel, Pleinlaan 2, 1050 Brussels, Belgium; \\ michael.distelmans@vub.be \\ * Correspondence: ilse.scheerlinck@vub.be
}

Citation: Distelmans, M.;

Scheerlinck, I. Institutional Strategies

in the Ridesharing Economy: A

Content Analysis Based on Uber's

Example. Sustainability 2021, 13, 8037

https://doi.org/10.3390/su13148037

Academic Editors: Margareta Friman, Lars Olsson and Hugo Guyader

Received: 20 May 2021

Accepted: 14 July 2021

Published: 19 July 2021

Publisher's Note: MDPI stays neutral with regard to jurisdictional claims in published maps and institutional affiliations.

\begin{abstract}
Recently, scholars have paid growing attention to ridesharing economy firms' institutional work to obtain legitimacy. More specifically, they have pinpointed the need for further research to better understand the actions of institutional entrepreneurs across geographical contexts. In this paper, we investigate Uber's institutional strategies in the Brussels Capital Region from 2014 to 2020. Using the theoretical lens of institutional entrepreneurship, we apply content analysis of press media to analyse Uber in relation to authorities, incumbents, drivers and users. We also delve into the tactical aspects of Uber's institutional work. The findings show that during the first years of operation, Uber predominantly used strategies of framing and lobbying. The company also made diverse articulations of theorization, collaboration, and negotiation. A more inductive reasoning reveals that market strategies also have a part in Uber's institutional work. According to the findings, Uber's quest for legitimacy in Brussels was not an unqualified success, due to conflicts and special interests complicating the market. We formulate recommendations on how actors may build a more sustainable market of ridesharing and provide some reflections on the theoretical framework.
\end{abstract}

Keywords: sharing economy; urban ridesharing; institutional entrepreneurship; Uber; Brussels Capital Region; legitimacy

\section{Introduction}

In recent years, various scholars have launched a new stream of research, studying the role of sharing economy organizations in shaping the institutional environment [1-5]. These new contributions are legitimate and deserve further continuation, given the growing importance that the sharing economy represents in business and society. While the term sharing economy is characterized by semantic richness and subject to scholarly debate [6], digging into the variety of definitions would go beyond the purpose of our study. For the sake of clarity and by way of guidance, we therefore refer to sharing economy as the range of peer-to-peer platforms that match the supply and demand of sharing services, so as to stimulate collaborative consumption and utilize idle capacity $[1,7,8]$. By using app-based information technology embedded in innovative business models, these platforms aim to facilitate services under regimes such as tourism, mobility, employment, and waste reduction $[1,9]$.

Notably, the disruptive nature of the sharing economy has posed significant challenges to the agendas of actors such as incumbent players and local authorities. Illustrative, in that respect, are the services in the ridesharing economy, with Uber as a dominant market player. Recently, incumbent companies of the taxi sector have shown responses ranging from being rather defensive to downright resistant towards Uber as a newcomer $[10,11]$. Local authorities, on their part, have been governing back-and-forth with mixed policy outcomes, that have often benefitted special rather than the general interest in the market of ridesharing $[3,12,13]$.

The often conflictive nature of the interplay between ridesharing companies' actions and the institutional environment $[3,12]$ has led scholars to address questions on how 
sharing economy companies attempt to gain legitimacy from governments in a particular market context. Being rooted in an extensive range of theories on institutional work and institutional entrepreneurship [14-19], the body of novel studies have generated interesting insights both empirically and theoretically [3,4,20,21].

Taking a contingency perspective, these studies show how sharing economy companies develop strategies aimed at changing regulations in a particular geographic, often city-level, context [21-23]. Although quite some companies in the sharing economy take a global position in the business arena (e.g., Uber, Airbnb), it remains important to focus on their local activity if we are to understand how their institutional strategies tend to differ according to the context in which they operate [21,24-26].

In an attempt to reshape the institutional environment, sharing economy companies act as institutional entrepreneurs. Institutional entrepreneurs, unlike classic entrepreneurs, operate under business models that deviate from models that had already prevailed in the institutional playing field $[5,19]$. Through a realm of strategic tactics, institutional entrepreneurs seek to change the way the market is organized [27] in the search for competitive advantage [8].

The novel nature of the phenomenon of sharing economy, and ridesharing in particular, has led scholars to call for more research focused on specific contexts, so as to enable cross-case and cross-context comparison $[3,21]$. Such an approach may add to a better understanding of the diversity of "regulatory responses of governments at local, national and supra-national levels" [7] (p. 9) in the field of sharing economy. Additionally, more longitudinal studies are encouraged, to learn more about the evolution over time of sharing economy companies' institutional work [4]. Our study seeks to address these gaps by examining Uber's institutional work in the context of the Brussels Capital Region (consisting of 19 municipalities, including the city of Brussels), henceforth referred to as Brussels, for the sake of brevity, except when the full name is needed for reasons of clarity.

Using content analysis, we address the following research questions: (1) 'Through which strategies of institutional work does Uber attempt to reshape the institutional context?' and (2) 'How does the city context of the Brussels Capital Region contribute to understanding Uber's efforts and (lack of) success in gaining legitimacy?'. Strategies of institutional work may range from the communication of visions and ideas for change to mobilization of resources, with the aim of reshaping institutions $[16,19,28]$.

Studying Uber in Brussels is interesting for various reasons. First, the company has international status and is highly visible when it comes to setting a foothold as a first mover in the market of ridesharing. Second, Brussels plays a key role, not only as a decisionmaking centre of the European Union, but also as a major hub for lobbyists. On a local level, the capital is also known for its heavily regulated taxi industry, which has fuelled intense conflicts since the arrival of Uber in 2014. Third, the findings of our study may further spark the debate on the role that new business models such as ridesharing services may play in sustainable mobility systems and smart city management $[6,29,30]$.

The literature in our paper used the integrative framework of institutional entrepreneurship developed by Pacheco et al. [17], and extended and tested by Klein Woolthuis et al. [31] and Pelzer et al. [3]. The framework integrates perspectives from institutional theory, institutional economics and entrepreneurship research (e.g., Lawrence and Suddaby [16]; Battilana et al. [19]) to describe the institutional entrepreneur as an actor who seeks institutional change to gain economic rent. We added a contingency perspective to address the need among scholars for analysing sharing services in specific contexts (e.g., Uzunca et al. [21]; Pelzer et al. [3]). We also made suggestions for theoretical adjustment, based on elements that emerged inductively from the data. This contributes to theories that state that institutional strategies consist of both market and nonmarket strategies [21,23,32], a classification that creates a broader view of how companies tend to reshape institutions. With our findings, we hope to enable cross-geographical comparison with findings from previous research on the subject. 
In our study, we also discuss what Uber's business model may signify for sustainability. The recent literature has addressed the impacts of the sharing economy on sustainability $[1,33,34]$, particularly in environmental, technological, economic and social terms. Some studies examined more specifically the sharing economy in urban contexts of sustainability (e.g., Gao and Li [35]; Zvolska et al. [36], Enochsson et al. [33]), while other studies have recently investigated the aspects of Mobility-as-a-Service (e.g., Jittrapirom et al. [37]; Narayanan et al. [38]). At this stage, research needs further elaboration, though it is not void of challenges in terms of methods and data [39]. While these studies do not fully align with our focus on Uber's institutional work, they have provided concepts to reflect on what Uber's institutional work may imply for sustainability in the urban context of Brussels.

The paper proceeds as follows. The next section presents the existing literature and outlines how concepts of institutional entrepreneurship might account for Uber's institutional strategies in the context of Brussels. Sections 3 and 4 describe the data collection, the method of content analysis, and the findings from various perspectives. In Section 5, we provide the discussion and conclusions of the findings. The section also addresses implications for sustainability in the context of Brussels. Section 6 addresses theoretical and practical implications and concludes with some limitations of the study.

\section{Literature Review}

For a good understanding of how companies are working to obtain legitimacy, we need to analyse the institutional strategies that they unfold in a particular institutional setting. Institutional strategies serve as a roadmap to the institutional entrepreneur, who aims at creating, maintaining or disrupting institutions through actions of institutional work [16].

In markets where governments and entrepreneurs interact to produce specific regulatory outcomes, legitimacy is a key factor influencing the entrepreneur's success in mobilizing resources in those markets $[27,40,41]$. By spreading knowledge about operations and influencing how authorities value business activities (referred to by Aldrich and Fiol [41] as, respectively, cognitive legitimacy and socio-political legitimacy), the institutional entrepreneur may gain acceptance among key stakeholders who are directly or indirectly involved in the entrepreneur's business process [8,40,41].

During the last few decades, the view of organizations as active influencers of institutions has gained growing attention $[14,16,17]$. This has sparked the debate on how these actors may reshape institutions, while at the same time being affected by these institutions [28]. It has become clear that, in order to become successfully embedded in markets, actors should go beyond meeting current regulations or conforming to existing rules [42,43]. Driven by self-interest, they leave their mark by enforcing institutional change to their advantage $[17,19]$.

Such actions also characterize companies in the sharing economy. Operating under business models that are often categorized, rightly or not, as disruptive [44], sharing economy companies put huge effort into overcoming obstacles [4] resulting from scepticism among public opinion and local authorities, and from resistance by incumbent industries facing the threat of new market entrants $[3,4,41]$.

Recent studies on the sharing economy (e.g., Zvolska et al. [4] on urban sharing organizations; and Uzunca et al. [21], Boon et al. [20]; Pelzer et al. [3], on Airbnb and Uber) generally confirm relevant theories of institutional work [14-18]. The studies have shown that the predominant strategies of institutional work are of a kind that surpasses the institutional status quo by creating or disrupting, rather than maintaining existing institutions [16].

\subsection{Contingency Perspective}

The recent contributions on institutional work in the sharing economy (e.g., Pelzer et al. [3]; Boon et al. [20]; Zvolska et al. [4]) have revealed the need for further investigation of the phenomenon across geographical contexts. This is based on the idea 
that context matters, since there is no one single way companies and institutions interact. Consequently, understanding context-related factors may help to explain which institutional strategies work well in which institutional environments $[8,19,23]$.

The success of changing the institutional environment depends on the company's strategic strengths, but also on the nature of the environment in terms of weak or strong regulations [23,45,46]. In their case study of Airbnb and Uber, Uzunca et al. [21] point out that city contexts which are characterized by weak institutions generally create more leeway to sharing economy companies for obtaining legitimacy, without having to face strong resistance from incumbents. Leeway is, on the other hand, more limited in cities with strong regulations, where tight connections between incumbents and regulatory authorities force the institutional entrepreneur to develop alternative institutional strategies [21,27]. Hence, context not only dictates how companies such as Uber need to mobilize their resources in obtaining legitimacy, but also influences the way conflicts with other actors are settled [22].

The relevance of context also becomes clear when differences in governance levels are highlighted. In that light, Hong and Lee [47] point out that in the sharing economy, policy makers at centralized governance levels tend to accommodate more easily to companies such as Uber than policy makers at a more decentralized, city level. The explanation is that the governance level tends to determine the distribution between the benefits (e.g., a more sustainable society) and the costs (disruption of incumbents), as perceived by policy makers [48].

It is noteworthy that the contingency perspective should not be at odds with the global market position that a company occupies [19,24]. More specifically, sharing economy companies such as Airbnb and Uber have global status, while facing challenges with competitors and regulatory authorities at the city level [8,21]. Therefore, analysing sharing economy companies' local operations may help to gain a better sense of their role as an institutional entrepreneur in effectuating institutional change in cities $[19,24]$. It may also help to understand the role that local key stakeholders play [8,25], and the impact they may have on the success of institutional entrepreneurs' actions in a given context [19]. Our research takes this contingency perspective by analysing Uber's institutional strategies in Brussels.

\subsection{The Framework of 'Coevolution of Institutional Entrepreneurship'}

For the analysis of the tactical nature of institutional strategies, we build on the framework of 'coevolution of institutional entrepreneurship' developed by Pacheco et al. [17], and adjusted by Klein Woolthuis et al. [31] and Pelzer et al. [3] to address institutional entrepreneurship, respectively, in the field of sustainable urban projects and ridesharing. The framework of Pacheco et al. [17] integrates perspectives from the literature on institutional theory, institutional economics and entrepreneurship research, to understand the institutional entrepreneur's legitimacy-seeking actions. The framework conceptualizes the institutional entrepreneur not only as an actor who seeks institutional change (the institutional theory perspective), but also as an actor who, driven by self-interest, seeks to change institutions with the intention of earning economic rent (the institutional economics perspective). By emphasizing the institutional entrepreneur's economic motivation and exploitation of opportunities, Pacheco et al. [17] highlight the concepts that classic and institutional entrepreneurship have in common $[19,49,50]$. This perspective contributes to exploring how sharing economy companies such as Uber utilize resources to change institutions $[19,51]$. Similarly to other internationally active companies, they play by the rules of both market and nonmarket logic to improve their competitive advantage [8,52,53]. To that end, they develop various strategies of institutional work, which will be discussed in the following paragraphs.

Through a strategy of framing, "institutional entrepreneurs seek to depict their preferred institutional arrangement as appealing to the widest possible audience" [17] (p. 990). In that light, a variety of tactics may be used. One common tactic is to share visions for change that find broad support in the institutional context $[17,19,54]$. Using a rhetoric 
for change, institutional entrepreneurs present their actions as a better, often superior, alternative to cope with current problems. Institutional entrepreneurs' articulations may go even further, as they invoke a sense of urgency or point to the need to break with old ways of running operations [19,54].

The process of framing may become more complex, as the institutional entrepreneur shows affinity with other actors in the playing field, while at the same time expressing the need for new rules [19]. An important element of this tactic entails convincing other actors in the market that the new rules equally apply to their benefit [55], which may help to strengthen the connection with like-minded actors.

Institutional entrepreneurs may also engage in framing by making persuasive identity claims on what they stand for, or what they do not [56]. In that regard, Pelzer et al. [3] found evidence on framing tactics used by UberPOP in Amsterdam, positioning itself as a technology company, rather than an operator in the taxi industry.

Through theorization, institutional entrepreneurs specify abstract (theoretical) categories to define cause-and-effect relationships that are relevant in their field of operations [17]. Theorization is an important element of institutional work that allows actors to either maintain, create or disrupt the institutional environment $[14,16]$. In institutional theory, theorization has been considered as a mechanism for building coalitions with key stakeholders who are directly or indirectly involved in the entrepreneur's operations [17]. A common tactic of theorization relates to institutional entrepreneurs' efforts to legitimize innovations by explicitly articulating how new technologies may contribute to solving specific problems in society [14]. Through the naming of new constructs [16,57], the entrepreneur uses rhetoric of cause-and-effect relationships fitting in the institutional context. Theorization, as well as framing, mainly exists by virtue of explicit communication, unlike other institutional strategies such as lobbying, collaboration, and negotiation (see infra), which also entail genuine actions to achieve regulatory change [58,59]. If theorization is effective, then the institutional entrepreneur will find support for the innovative way in which operations may be run, and eventually succeed in having the innovation diffused [60]. In the sharing economy, companies tend to use theorization mostly with the intention of creating or disrupting, rather than maintaining, institutions [4]. More specifically, sharing companies tend to theorize about how their operations may contribute to sustainable mobility systems (in case of ridesharing, e.g., Pelzer et al. [3]), or how they may be beneficial for actors (such as users and authorities) in a broader, societal context (in case of home sharing, Boon et al. [20]).

Another institutional, nonmarket strategy is lobbying, which is used among institutional entrepreneurs to improve their competitive advantage by (pro)actively influencing the institutional context $[23,61]$. Through efforts of advocacy work, lobbyists mobilize resources to shape norms and beliefs that are relevant in their playing field, with the intention of obtaining political support [16]. While lobbying is challenging to define and measure $[62,63]$, it generally refers to a variety of efforts such as providing information and financial incentives, to affect institutional decision making $[45,59,64,65]$. Not seldom, and this also applies to the sharing economy, actions of lobbying take place behind the scenes [58], though there is evidence of actions trickling down via the media to the public [3]. Lobbying activities may be conducted either at the individual corporate level or through collective action [45]. Focusing on the individual lobbyist is insightful, especially when the institutional entrepreneur is sufficiently powerful to take individual initiative in seeking more legitimacy $[17,45]$. More specifically, when entrepreneurs have good financial provision and knowledge skills for influencing public policy, they will more likely lobby authorities on individual initiative [45]. Individual lobbying also typifies firms in the sharing economy [4]. Ridesharing companies such as Uber, for example, tend to be quite aggressive and non-compliant when it comes to influencing city authorities [3,21]. Such behaviour cannot be considered in isolation from the strong opposition built by incumbents in the industry. Such dynamics tend to spark a context of 'dog eat dog', where the 
ridesharing company, in its role of institutional entrepreneur, does not hesitate to mobilize users towards lobbying policy makers, sometimes by way of social media [22].

Through collaboration, institutional entrepreneurs tend to participate in lobbying based on collective instead of individual actions [23]. They seek advantages that are hard to attain on an individual basis [66], while they capitalize on common interests shared with other actors to increase power over institutions $[17,45]$. The importance of collaboration as a source of institutional change has also been demonstrated by Lawrence et al. [67]. Lawrence and colleagues have emphasized that collaboration entails an entire process, whereby the institutional entrepreneur builds relationships and connects with other actors to diffuse new technologies beyond the context in which collaborations take place. Building these relationships may add to institutional entrepreneurs' credibility and reputation in the long term [45]. However, collaborative undertakings do not always run smoothly, since they form part of a complex political process that involves multiple interests [19]. More specifically, when the institutional entrepreneur aims to introduce its technology as a common standard, other partners will have to be convinced of that standard. In highly disruptive markets, this may be complicated, since the institutional entrepreneur often faces strong resistance from incumbents who experience the new technology as a serious threat [68]. This is a point of attention, since the adoption of the technology by other organizations is key for having innovative technologies effectively institutionalized [67]. The complicated situation also characterizes the sharing economy, where firms undertake collaborations with governing authorities, and far beyond [21]. Key relationships with multiple stakeholders are built with the purpose of diffusing disruptive innovation [12,21]. While disruption is clearly the main purpose of companies such as Uber, the debate remains about whether the outcome of the company's institutional efforts is genuinely disruptive $[3,44]$. In this regard, the collaborative actions that Uber undertakes with business partners and other actors in the market [3] may, if not disrupt, at least help them to transform the incumbent industry [44].

Building on the 'contractual form', conceptualised in institutional economics as a mechanism for institutional change [17], Klein Woolthuis et al. [31] proposed negotiation as an institutional strategy in the context of urban sustainability projects. Through negotiation, institutional entrepreneurs make formal or informal arrangements to operate their innovative business models at favourable terms $[17,20,31]$. In city contexts of ridesharing, institutional entrepreneurs such as Uber use negotiation tactics by initiating talks, at times aggressively loaded, with local ministries over licenses and technical requirements [3]. In a broader context, sharing economy firms use negotiation as a tactic to influence the perceptions of key stakeholders such as incumbents, platform users, and institutional authorities to exploit novel business undertakings [21].

During the coding process, our attention was drawn to a category that is linked with the concept of market strategy. Through market strategies, firms set up actions of discounts and free rides, as well as investments in infrastructure [21], with the purpose of increasing market share and improving economic performance [8,32]. Market strategies differ from nonmarket strategies, the latter whose main purpose is to increase a company's power over institutions. The category of market strategy, which emerged inductively from the data, may contribute to the theory that considers market and nonmarket strategies as two subsets of institutional strategy. The institutional entrepreneur combines both subsets to jointly improve legitimacy and competitive advantage $[23,32,45,46]$. Considering this market strategy may create a broader view of how Uber works towards shaping the institutional context. In their case study analysis, Uzunca et al. [21] confirm that sharing economy firms such as Uber and Airbnb use both market and nonmarket strategies to increase legitimacy and improve competitive advantage in specific city contexts.

In the literature, the argument has been made that the use of institutional strategies tends to follow a particular time order. More specifically, institutional entrepreneurs would first tend to develop strategies based on vision sharing (made concrete in our paper through framing and theorization), to subsequently mobilize resources in a next stage (e.g., through 
strategies such as lobbying and collaboration) $[19,69]$. Inspired by the empirical work by Pelzer et al. [3] on Uber in Amsterdam, for which no evidence on a possible order was found, we test whether such time order characterizes Uber's institutional work in Brussels.

\section{Methodology}

The empirical part of our research is based on content analysis of textual data from media sources. The technique, which in this paper follows both a quantitative and qualitative approach, provides several advantages. With no active participants involved in the data process, content analysis offers the benefit of obtaining data on actors' behaviour in an unobtrusive and non-reactive way [70]. If carried out with attention to issues of validity and reliability, content analysis may allow for an objective, transparent and rigorous scanning of the data resulting from the documents [71]. Although content analysis has suffered from the myth of lacking theoretical backdrop and mainly focusing on what is measurable $[70,71]$, thanks to scholarly progress and incremental insights, the method has proved suitable both as a deductive and inductive scientific approach [72-75]. The approach of our study is mainly deductive, since it applies existing theory to data gathered from press content $[73,76]$. Through this approach, we hope to facilitate replication in future research. Our study also contains an element of inductive reasoning, as we developed a category grounded in the data [72,77]. By taking this two-way approach, we hope to stimulate new insights into the novel and so far underexplored subject of institutional work in the sharing economy.

\subsection{Sample and Data Collection}

We selected data from the five largest Belgian newspapers (De Tijd, de Standaard, De Morgen, Le Soir and La Libre Belgique), a Brussels local newspaper (Bruzz), and a Belgian weekly business magazine (Trends/Tendances, issued in Dutch and French). All media sources cover the major geographical regions in Belgium in terms of readers' audience (Flanders, Wallonia, and Brussels) and maintain high standards of objectivity, integrity, and representativeness. We accessed the sources through Go Press Academic, the scholarly media database, except for the local Brussels newspaper, which offers free access to archives. A small-scale pilot scan pointed out that the sources were eligible for identifying content on Uber's strategies of institutional work. We applied a search query using the keywords 'Uber' and 'Brussel' (Dutch name) or 'Bruxelles' (French name). We were interested in all business services operated by Uber (UberPOP, UberX, UberBLACK, and UberVAN) since its entry into Brussels, so as to create a full picture of the company's strategies of institutional work in Brussels. The media scans covered a seven-year period from 1 January 2014 (the year when Uber entered into Brussels) to 31 December 2020 (the most recent full calendar year of the analysis). In total, we retrieved 1860 articles, of which 483 eventually had the right scope. All 483 articles were used for describing the history context of Uber's institutional work in Brussels. After the deletion of duplicates of articles reporting on the same event, we ended up with 91 quotes that were useful for identifying institutional strategies (see Table 1).

Table 2 lists the different steps of the coding process in detail. Using the guidelines of content analysis developed in Hsieh et al. [73], Erlingsson and Brysiewicz [78], and Bryman [70], we divided the full article texts into shorter texts, referred to as meaning units. Subsequently, we reduced the meaning units down to condensed meaning units in the form of quotes, while preserving the core content of the quotes. In a next step, we labelled the condensed meaning units with codes. The codes were subsequently assigned to the categories, representing the strategies of institutional work. We ensured that the categories were unidimensional, exhaustive and mutually exclusive [71]. During the process, we were also able to identify sub-codes that we could assign to sub-categories. While the categories represent the main strategies of institutional work as rooted in the theory, the sub-categories provide more detailed information on the way Uber articulated these strategies with a view to obtaining legitimacy in the context of Brussels. While many of the sub-categories 
can be interpreted against the backdrop of the theory of institutional work, some other sub-categories reveal that the Brussels context matters in understanding the institutional work of ridesharing companies such as Uber.

Table 1. Process of content analysis—search and extraction process.

\begin{tabular}{|c|c|}
\hline Steps & $\begin{array}{c}\text { Number of } \\
\text { Articles or Quotes }\end{array}$ \\
\hline $\begin{array}{l}\text { Search process of written media press in Go Press Academic database } \\
\text { (newspapers) and Bruzz, local Brussels newspaper } \\
\text { Search terms: [‘Uber' AND 'Brussel'] // ['Uber' AND ‘Bruxelles'] } \\
\text { Time period of media coverage: } 1 \text { January 2014-31 December, } 2020\end{array}$ & 1860 articles \\
\hline $\begin{array}{c}\text { Content for history analysis } \\
\text { Removal of articles with irrelevant scope, based } \\
\text { on the following criteria: } \\
\text { Core news not on Uber; Uber only mentioned as an example; Uber in } \\
\text { geographical location different from Brussels }\end{array}$ & 483 articles \\
\hline Identifying quotes, after removal of duplications, referring to categories & $\begin{array}{l}74 \text { articles with } \\
\text { minimum one } \\
\text { quote }\end{array}$ \\
\hline $\begin{array}{c}\text { Assigning quotes to the six categories of strategies (five from theory and } \\
\text { one category of 'market strategy') }\end{array}$ & 91 useful quotes \\
\hline
\end{tabular}

Table 2. Process of content analysis—coding process.

\begin{tabular}{|c|c|}
\hline Steps & $\begin{array}{l}\text { Terms Used in } \\
\text { Content Analysis }\end{array}$ \\
\hline $\begin{array}{l}\text { Reading full-length articles-searching for relevant content } \\
\text { Selection of appropriate paragraphs }\end{array}$ & Meaning unit \\
\hline $\begin{array}{l}\text { Removal of duplicates of press releases on same news event } \\
\text { Shortening the text into quotes while still preserving the core meaning }\end{array}$ & $\begin{array}{l}\text { Condensed } \\
\text { meaning unit }\end{array}$ \\
\hline $\begin{array}{c}\text { Assigning codes (labels) that describe each condensed meaning unit in one } \\
\text { or a few words }\end{array}$ & Code \\
\hline Grouping the codes based on the institutional strategies & Category \\
\hline Assigning sub-codes to identify subcategories & Sub-code \\
\hline Grouping the sub-codes-theory- and exploration-based & Sub-category \\
\hline
\end{tabular}

Source: Hsieh and Shannon [73]; Erlingsson and Brysiewicz [78]. Quotes were coded using the NVivo software package.

\subsection{Method}

We analysed the data from the content analysis (available in the Supplementary Materials) to serve three purposes [71,73].

First, through an in-depth and open-ended analysis, we could map out Uber's history of actions related to institutional work in Brussels. Comparable to case study design, this approach contains a substantial element of narrative, by offering a holistic and layered storytelling of Uber's institutional strategies in Brussels [70,71,79]. Through this approach, we were able to map out the dynamic character of ridesharing in Brussels, with a focus on Ubers' intentional actions, as well as responses by incumbents and authorities.

Second, by turning coded texts into numerical information, we were able to add a quantitative element to the data. For the period of 2014-2020, we computed the frequency with which words or quotes occurred in the media texts, in accordance with the strategies defined in the theory [72]. The approach also enabled us to identify the ups and downs in Uber's activity of institutional work over time by registering which institutional strategies tended to predominate.

Third, against the theoretical backdrop of institutional work, we used the coded texts to analyse the different categories in a qualitative way [71]. Putting emphasis on the content 
and meaning of each category allowed us to deepen the understanding of Uber's strategies of institutional work. While this approach mainly adds to a deductive reasoning by testing existing theory, it has also created room for a more inductive approach by building a category grounded in the data [71,72].

\subsection{Validity and Reliability}

Since coding procedures are subject to biases [76], we took several measures to address the (1) construct validity, (2) internal validity, (3) external validity, and (4) inter-coder reliability of our findings.

First, to ensure construct validity, we collected the information from mainstream Belgian newspapers (from centre-right to centre-left on the political spectrum) involved in high-quality economic and corporate reporting on Belgium and Brussels. This approach allowed us to work with a broad-scope and diverse set of text material, appropriate for identifying categories in accordance with the concepts from the theory $[70,74,75]$.

Second, the internal validity was strengthened by including a longitudinal element in our content analysis. The time horizon from January 2014 to December 2020 enabled us (i) to ensure sufficient congruence between the concepts and the data; (ii) to warrant stability, by minimizing the coincidence of observations from the data; and (iii) to check for an order of occurrence in Uber's institutional strategies [70].

Third, we also gave thought to the generalizability of the results to other contexts and actors to address the issue of external validity. Generalizing results from a study on a rather new phenomenon in a specific context has its limits, due to the non-random sampling characterizing media text analysis [80]. We, therefore, extracted the maximum out of the data sample by scanning the text for the purpose of both history writing and analysis of Uber's strategies. We further attempted to strengthen validity by considering a time horizon that spans about Uber's total length of stay reached so far.

Fourth, the inter-coder reliability was addressed by dividing part of the coding work among the two authors. Coding is, however, a time-consuming process, which makes it unrealistic to have all content coded by both researchers [81]. Therefore, duplicate coding work was carried out for only a subset of the sample [82,83]. More specifically, the two authors independently conducted the stage of assigning the condensed meaning units (in the form of quotes) to the various categories, thus meeting the minimum of $10 \%$ duplicate coding work, as recommended by Hodson [82]. In the case of divergent views on the outcome, the authors reached consensus through discussion. When the outcome was inconclusive, the observation was not used.

\section{Findings}

This section provides an overview of the findings. First, we start out with a broad outline of Uber's institutional work in the context of Brussels. The longitudinal dimension along with the narrative element help to map out the process by which Uber's strategies have unfolded over time. While the main focus lies on Uber's actions, this case-type part of the findings also sheds light on actions and views by other actors in the market such as incumbents, drivers, users, and policy makers at the city level. Second, we provide a timeline of the frequencies with which quotes or words that refer to institutional strategies were found in the text material. The results show the ups and downs of Uber's efforts to obtaining legitimacy. Third, we capitalize on the richness of the data by describing Uber's different strategies of institutional work in depth. We discuss the findings with reference to the theory of institutional work.

\subsection{Uber in the Context of Brussels: A Brief History}

\subsubsection{Period 2014-2015: The Launch of UberPOP and UberX}

Uber's entry into Brussels on the 25th of February 2014 did not go unnoticed. Deploying an online app and secretly recruiting drivers in and around Brussels, the company launched UberPOP, its first ride-hailing platform. Through the platform, users and un- 
licensed, non-professional drivers were brought together. Soon after the launch, the incumbent taxi drivers in Brussels were poised to take protest action against UberPOP's operations. Despite the claim of the Brussels Minister of Public Transportation, Brigitte Grouwels, that Uber was illegal and had to comply with existing regulation, the company continued to operate ride-hailing services, using promotional activities such as free rides. In April 2014, the Court sustained complaints filed by taxi associations that Uber was not a legal taxi company, which forced the company to cease operations under threat of penalty. A wind of change blew in favour of Uber when Neelie Kroes (Vice President of the Commission and Commissioner for the Digital Agenda) expressed her disagreement with the Court's decision and the view of Brussels authorities. Her view that the Court's decision mainly ruled in favour of the supposed 'taxi cartel' and not the users was further echoed at the city level, where political parties urged the government to make the taxi law 'Uber proof'. A striking observation was the quick turnaround made in mobility policy conducted in Brussels. At the end of 2014, Pascal Smet (at that time, newly appointed as Minister of Mobility in Brussels) ordered police on behalf of the Brussels government to enforce a de-activation of the Uber app in Google's and Apple's app stores. Only a few months later, in February 2015, however, the same Minister of Mobility announced plans for a new taxi regulation in Brussels. The playing field that resulted from the new regulation would clearly embrace new market players such as Uber, given the stipulations such as the listing and self-employment status of drivers, as well as the obliged insurance policies imposed on cars and users. The heavy counter reaction by the taxi drivers made the relationship with Uber drivers and Brussels government deteriorate from bad to worse, which eventually culminated in new protests. The quick change in policy making combined with conflictive chain reactions was an indication of busy activity of institutional work on the part of Uber, which is also confirmed by our findings under Section 4.3. In September 2015, Uber launched UberX, a service that would operate with professional drivers under limousine permit, at slightly higher fares. However, with UberPOP still operating in the market, conflicts lingered on as taxi drivers organized new protests and reported evidence of Uber lobbyists having breakfast meetings with the Brussels Minister of Mobility. The struggle for power among authorities, incumbents and Uber finally settled on 25 September, when the Brussels Court of Commerce ruled that UberPOP should shut down operations on grounds of illegality. Efforts by Uber to obtain legitimacy for UberPOP through an online petition, signed by more than 25,000 users, did not help to counter the decision.

\subsubsection{Period 2015-2020: UberX, UberBLACK and UberVAN}

The shut-down of the UberPOP service redirected the incumbents' target towards UberX, which was also alleged to violate the Brussels taxi legislation. A grey zone of rules was governing the playing field of ridesharing, as the spokesman of the Minister of Mobility argued that UberX did not comply with the spirit of the law on limousine services, which required a written contract of at least three consecutive hours at a minimum price of EUR 90. Uber, who framed the requirements to be anti-competitive and feeding monopoly power, responded by establishing the 'Platform Rider Association', a platform that was to organize limousine services, but was, in legal terms and according to public opponents, regarded as dubious. In April 2016, the Brussels Minister of Mobility proposed a new taxi plan for Brussels. The new plan would create additional benefits for the traditional taxi drivers, for example, in the form of tax cuts and app-connected digital taxi meters. The plan would also tackle issues of licensing, registration and transparency that had arisen with Uber's entry into Brussels. The ultimate aim was to create a level playing field of social and fiscal terms under which both private and taxi drivers were to operate. While the plan still distinguished between the taxi service and the limousine service - the latter operated by Uber-the idea of the Minister was to propose an updated plan that would stipulate one single regulation for both services, and replace the digital taximeter with an app to be used for all services. The proposals, however, ended in a deadlock, as taxi drivers, backed up by Febet (Federation of Belgian Taxi Drivers) and 
the French-speaking socialist party, continued to protest against the proposal. While the newly proposed taxi plan remained a dead letter, Uber continued its operations under limousine terms by differentiating towards new, more luxurious services using professional drivers: UberBLACK and UberVAN, launched half in 2016 and half in 2017. This business approach was set to be the only one left after Uber had lost an appeal against the Court's ruling that UberPOP (operating with non-professional drivers) was illegal. The ruling had shifted the focus of the protests towards the services that were still operating in the Brussels market. The lack of a fundamental and sustainable framework to regulate taxi services in all its aspects had created a lacuna that had mainly been filled up by legal disputes and settlements ranging from "Uber is not a digital company, but a company operating under the classic taxi regulation" (decision by the European Court of Justice, December 2017) to "Uber is totally legal" (French-speaking corporate court of Brussels, January 2019).

\subsection{Institutional Strategies: Timeline of Frequencies}

Against the background of the theory, this section reports on the frequencies of Uber's institutional strategies in Brussels: framing, theorization, collaboration, lobbying, and negotiation. A sixth category, market strategy, emerged inductively from the coding process. As indicated in Figure 1, most of Uber's institutional work took place in 2014 and 2015, with, respectively, 43 and 29 cases. Back then, the company entered the Brussels market with the launch of UberPOP which, due to its legal controversy, was soon succeeded by UberX. Notably, Uber's institutional work further declined in 2016 and 2017, when, as described under Section 4.1, the company had to face several complaints and await the Court's decision regarding its (il)legality. Uber's institutional work smoothly picked up again in 2019 and 2020, when the company, facing growing resistance from the taxi federation, started to differentiate its strategy towards UberBLACK and UberVAN. The results show that Uber's institutional work mainly entailed, in order of importance, strategies of lobbying (33 cases), framing (30 cases) and collaboration (12 cases), followed by theorization (11 cases), market strategies (3 cases) and negotiation ( 2 cases). It is noteworthy how in the first two years Uber's strategies of vision sharing (mainly through framing and, to a lesser extent, theorization) were immediately combined with strategies based on mobilizing resources (mainly through lobbying and collaboration), thus indicating the absence of any specific time order in the use of strategies. The findings in Section 4.3 will cover the tactical aspects of the institutional strategies in depth.

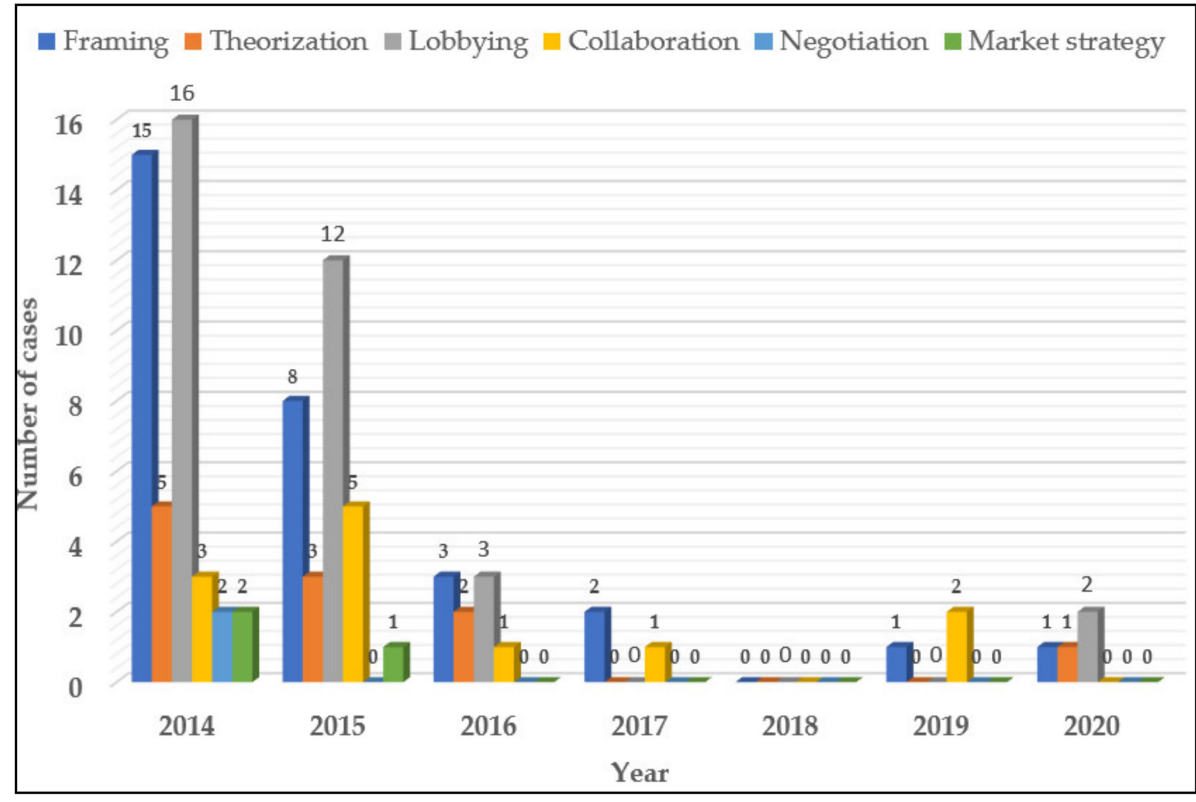

Figure 1. Strategies of institutional work-number of cases per category per year. 
The marked decrease in Uber's institutional work that set in after 2015 is worthy of reflection. From what we observed under Section 4.1, we suggest two possible explanations for this pattern. First, the early years of foreign market operation are a period when companies are still unfamiliar with the new context. As a result, they tend not to miss the moment to exploit any tactic that might help to reshape institutions to their benefit. This early stage may give incumbents time to prepare responsive actions by mobilizing resources against the newcomer. Our findings indicate an upsurge of such actions in 2017 and 2018, due to manifestations initiated by the Brussels taxi sector against the newly proposed taxi law.

Second, the strong resistance by the taxi sector may have triggered the change of course that Uber undertook with the launch of new services such as UberBLACK, -VAN, and $-X$. Rather than continue with visible tactics, Uber exploited loopholes to comply with the limousine law. This may suggest that Uber's tactics had become more subtle and less salient in the media, which is not surprising, given the company's progress on the learning curve of institutional work.

During the coding process, we were able to further refine the strategies of framing and lobbying into sub-categories. In general, most of the strategies revealed further tactical details. As Table 3 indicates, Uber used a strategy of framing by referring to old regulations governing the taxi sector (13 cases); the company's compliance with operational requirements for drivers (6 cases); and the use of identity claims (11 cases). In terms of lobbying, we found activities by the company at two levels of policy making: the Brussels Capital Region (25 cases) and the European Union (8 cases). With regard to theorization, Uber defined various cause-and-effect relationships (11 cases) by articulating the value added of its business model in terms of innovation and sustainable mobility. Strategies of collaboration (12 cases) were mainly undertaken with other private actors, such as Brussels Airlines and competitors. Other collaborative efforts reached out to taxi drivers and the local government. While market strategy mainly involved discounts and free rides offered to users, the strategy of negotiation was, though clear-cut, only minimally used.

Table 3. Uber's strategies of institutional work.

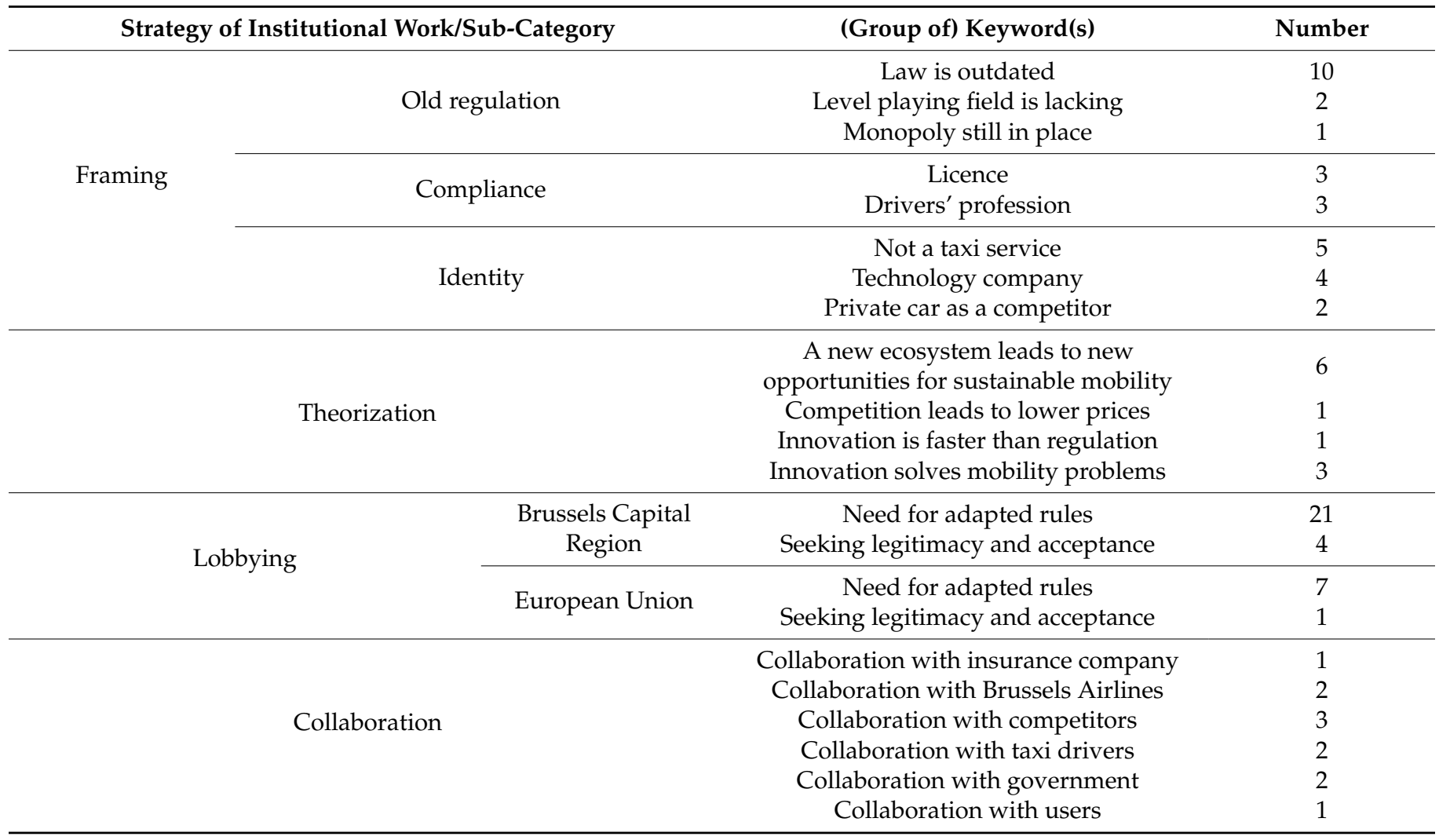


Table 3. Cont.

\begin{tabular}{cccc}
\hline Strategy of Institutional Work/Sub-Category & (Group of) Keyword(s) & Number & 1 \\
\hline & Collaboration with public transport & 2 & 3 \\
\hline Negotiation & Preparedness to talk & Price strategies of discounts and free rides & 3 \\
\hline
\end{tabular}

\subsection{Uber as an Institutional Entrepreneur in Brussels: Strategies of Institutional Work}

In this section, we discuss Uber's institutional strategies more in-depth, by referring to theory and proposing adjustments based on the data.

\subsubsection{Framing}

With regard to framing, Uber made various attempts to legitimize its position through narratives on three subjects related to the market of ridesharing in Brussels: old regulation, compliance and identity. First, in terms of old regulation, Uber explicitly emphasized the outdated character of the taxi law that preserved incumbents' monopoly power at the cost of a level playing field in the Brussels market. More specifically, in 2014 and 2015, soon after the launch of UberPOP, the company stressed the urgent need for adapting the outdated law to new technologies:

"The Brussels transport regulation existed for decades before the arrival of the internet. It may be time to ask the question of how to adapt this technology to the needs of the inhabitants."

(Pierre-Dimitri Gore-Coty, General Manager at Uber Western Europe, in La Libre Belgique, 17 April 2014).

Similar evidence on Uber highlighting the outdatedness of the law was found by Pelzer et al. [3] who, in their study on UberPOP in Amsterdam, referred to the 'anachronism argument' as an underlying element of Uber's strategy of framing. Our findings have shown how Uber tried to persuade others that the old regulation was the problem, rather than Uber. Efforts of definitional work [16] were made to further extend rhetoric to new laws. Uber even pushed the framing beyond the boundaries of the Brussels Capital Region by pointing at the potential conflict between local jurisdiction and the freedom of movement of businesses as stated by the EU:

"The question is whether this is not contrary to the higher principles such as the freedom to do business and the free movement of services in the European Union"

(Lawyers of Uber in Bruzz, 9 September 2015).

A second subject of framing related to Uber's efforts to ensure compliance with existing regulations. Uber repeatedly stressed that it met requirements in terms of licensing and other activity certifications related to drivers' professions. This was the case for UberPOP and later UberX, in agreement with Brussels Minister of Mobility:

"We work with drivers who have a license for paid transport, a medical certification, a certificate for technical conformity, a VAT number, etc. They have a contract of more than three hours spread over different journeys, which complies with the law. The Minister of Mobility, Pascal Smet, agreed to this principle."

(Filip Nuytemans, General Manager at Uber Belgium, in La Libre Belgique, 14 October 2015).

Uber continued to frame these issues of compliance up until 2020, when it initiated plans to expand into other cities in Belgium. As part of its compliant behaviour, the company presented itself as a solution to the alleged problem of undeclared work that still persisted in a sector supportive to cash. 
"We offer a solution for undeclared work. All payments on the Uber network are made by credit card and are traceable. That's a big step forward in an industry where cash is still the rule."

(Filip Nuytemans, General Manager at Uber Belgium, in De Morgen, 13 December 2014).

To put things in perspective, this frame should be mirrored against the view of the Public Social Security Service of the Belgian Federal Government that in 2019 classified Uber drivers as workers, not independents.

Clearly, this second subject of framing highlights the central role of drivers in Uber's framing of regulatory aspects such as licensing, VAT issues, medical certification and technical conformity. Uber's reference to drivers in its framing tactics makes sense, since drivers occupy, along with users, a key position on the online platform market where services of ridesharing are traded. Importantly, as Uber switched from the UberPOP to the UberX service, the company tackled a major legality issue by henceforth working with licensed drivers. The commitment was an important step towards compliance with norms of social sustainability in the context of Brussels.

A third subject of framing expressed by Uber is about how the company defines and positions itself in relation to the incumbents in the market of taxi services. Our findings showed how Uber positioned itself as a company that differs from the traditional taxi business. More specifically, during the period 2014-2019, the company proclaimed itself as a technology company that liaises supply and demand in the market of ridesharing services, while adding value to the local economy.

"One thing is sure: we are not a technology company like others: 75 to $80 \%$ of prices charged go directly into the pockets of the citizens of Brussels."

(Travis Kalanick, CEO at Uber, in Trends, 09 June 2016).

"Uber is a technology company, but unlike other companies in the tech world, we only earn our income from these service fees."

(Joost Verdiesen, Operations Manager at Uber, in Le Soir, 11 February 2017).

These observations, alongside Uber's claim that the private car, and not the taxi sector, is the main competitor, is in line with Pelzer et al. [3], who provided evidence of UberPOP in Amsterdam seeing itself as "an actor operating outside the taxi field" [3] (p. 7).

\subsubsection{Theorization}

Our findings also showed clear-cut indications of Uber's involvement in theorization. The strategy was expressed in four cause-and-effect relationships featuring the ridesharing context in which Uber operates as an institutional entrepreneur. The first two most common cause-and-effect relationships, particularly expressed under UberPOP in 2014 and 2015, were about the way Uber claimed to contribute to more sustainable mobility plans in Brussels through its active role in creating a new ecosystem and boosting innovation. By taking this approach, Uber could make clear why its way of operating ride-hailing services would be superior to the old way of doing business, thus breaking with business traditions from the past $[16,31]$ :

"Public transport alone is not enough, it is an unfair ecosystem that does not connect everyone. Uber makes that complete. We are an answer to the status quo in the transportation sector. An alternative to a world that looks like a parking lot and progresses like a monster traffic jam."

(Travis Kalanick, CEO at Uber, in De Tijd, 05 June 2015).

These findings on theorization demonstrate how Uber showed in the media its preparedness to work on sustainable mobility systems in Brussels, by solving issues of traffic congestion, parking capacity and carbon dioxide emission. Additionally, the idea of an ecosystem wherein car and bike sharing might replace individual car ownership was 
explicitly addressed to key stakeholders such as the Brussels government and providers of public transportation.

Uber also stressed the role of innovation in resolving mobility problems during the COVID-19 pandemic, by offering help and special discounts to medical staff in need for urgent transport services:

"Although Belgians are invited to stay at home as much as possible, there are people who have to travel to meet their family responsibilities. We want to support them in these difficult times and give them the opportunity to be transported comfortably and safely to their destination."

(Laurent Slits, Head of Uber Belgium, in Bruzz, 27 April 2020).

A third cause-and-effect relationship stressed how the market could benefit from more competition through lower prices if Uber would gain further foothold. Although we counted only one such cause-and-effect relationship, it symbolizes the institutional entrepreneur lecturing society on the principles of competition, as rooted in micro-economics. Pelzer et al. [3] made a similar observation of theorization, more specifically on how the platform may help to match supply and demand in a more efficient way.

As a fourth cause-and-effect relationship, Uber linked regulation with innovation through the adage 'innovation is faster than regulation' [3,69]. Playing the role of innovatorinstitutional entrepreneur, Uber prefers to create new regulations $[16,17]$ rather than undergo the effects from regulation on operational innovation [84]. Uber takes such a position in the hope that, by imposing innovation, regulation will follow suit [3] (see also Boon et al. [20] for efforts by Airbnb).

\subsubsection{Lobbying}

Our findings also highlight Uber as an actor lobbying the governments in order to gain legitimacy. Lobbying efforts may be based on collective or individual action $[17,45,64]$. While Uber's lobbying strategy mostly entailed individual efforts, its collective efforts were mainly based on collaboration with other actors in the playing field (see Section 4.3.4). These efforts ranged from advocating the need for an adapted regulatory framework to introducing itself as a legitimate contributor to local employment and sustainable smart city standards, in a quest for more acceptance.

"We make the mayors, politicians and civil servants understand that it is possible to create tens of thousands of jobs and reduce air pollution. Not by simple conviction but on the basis of figures and external studies."

(Travis Kalanick, CEO at Uber, in Trends, 09 June 2016).

Notably, Uber directed its efforts at two governance levels: the Brussels Capital Region and the European Union. This two-tier lobbying approach is not surprising, since Brussels occupies a position both as capital city of Belgium and centre of EU decision making. This double function is attractive to companies seeking to optimize lobbying efforts.

A major bone of contention in the legitimacy process has been the contract classification of Uber drivers. Our findings confirm that, already in 2015, Uber tried to counter debates on the legality of drivers' statutes by stating that labour contracts were drawn upon agreement with the Minister of Mobility, though the latter denied this.

"The Uber responsible also states that the contract was drawn up in consultation with Mobility Minister Pascal Smet, something that his cabinet denies."

(Uber in Bruzz, 19 October 2015)

Uber's lobbying activity was strikingly intense in 2014 and 2015, when UberPOP was making inroads into Brussels. This was the period when Uber lobbyists organized breakfast meetings with the Brussels Minister of Mobility, much to the frustration of the incumbent taxi sector (see Section 4.1 for a more contextual discussion of this observation). Particularly noteworthy is the similar evidence found by Pelzer et al. [3] of UberPOP's 
intensive lobbying activity, based on the same approach of 'breakfast meeting' in the early period of 2014-2015 in the city of Amsterdam.

In an effort to lobby for more legitimacy, Uber clearly did not leave untapped the advantage of Brussels as a playing field at the heart of the European Union. An example is its attempt to capitalize on interventions by Neelie Kroes, Vice President of the Commission and Commissioner for the Digital Agenda, who expressed herself negatively about Brussels' opinion against Uber's operations:

"Uber is here to stay in the Belgian capital, especially since we were encouraged by the Vice President of the European Commission Neelie Kroes, firmly opposed to this decision. According to her, we must stop protecting actors in an artificial way. I hope this position will resonate with many public authorities and regulators around the world."

(Dimitri Gore-Coty, General Manager at Uber Western Europe, in La Libre Belgique, 17 April 2014).

Uber lobbyist, Mark McGann, invoked his power at EU level to enforce a breakthrough at Brussels level:

"If member states like Belgium do not decide to modernize the regulatory framework, a European solution will be imposed."

(Mark McGann, Uber head of policy EMEA, in Le Soir, 04 September 2015).

Following the low activity of institutional work from 2017 to 2019, Uber's lobbying actions began to revive in 2020, in response to a lawsuit filed by the Belgian Taxi Federation (FeBet), claiming the illegality of Uber's platform-based operations in Brussels.

\subsubsection{Collaboration}

In 2014 and 2015, Uber strived to take a firm grip on the Brussels market of ridesharing. Our observations have shown how Uber built strategic collaborations to obtain legitimacy through consolidation of power. Seeking to share a common objective [31], Uber collaborated with the local public transport company, with insurance companies (to insure drivers), and with Brussels Airlines (for discounts on Uber rides). Competitors such as Djump were approached in 2015 to increase influence on the drafting of a new taxi law:

"In the meantime, Uber and Djump have welcomed Pascal Smet's project in a joint press release. 'The leadership shown by the Brussels government shows that affordable prices, public safety and consumer choice are perfectly compatible', they indicated."

(Uber and Djump in Le Soir, 28 February 2015).

Data have also revealed network-based approaches in 2016 between Uber and incumbent taxi drivers, who joined on a full-time basis or in combination with the job of taxi driver. According to Filip Nuytemans, General Manager at Uber Belgium, the main reason taxi drivers started to join, was as follows:

"More and more taxi drivers are also inquiring about becoming drivers on our platform. I think the situation in the taxi business is not ideal. For them, this is the opportunity to become their own boss."

(Filip Nuytemans, General Manager at Uber Belgium, in Le Soir, 12 May 2016).

\subsubsection{Negotiation}

While negotiation as a strategy is rather implicitly mentioned in Pacheco et al. [17], it has been conceptualized by Klein Woolthuis et al. [31] and further tested by Pelzer et al. [3] as a tactic of institutional work in the city context. Since the scope of research in both studies (sustainable urban development in Klein Woolthuis et al. [31] and Uber in Amsterdam in Pelzer et al. [3]) is in line with our study subject, we included the strategy of negotiation in our analysis. Including this strategy has enabled us to make comparisons in terms of theoretical and practical implications. Although our observations provided only limited support for negotiation as a strategy, some findings are worth discussing. In 2014, when the UberPOP service entered the Brussels market, Uber expressed 
two times via the media its preparedness to talk with the Brussels government. While the frequency of occurrence of negotiation as a strategy is limited, it is in line with the timing of UberPOP's negotiation strategy in Amsterdam [3].

"Rather than talk to us, the government is leaking material to the media. This makes clear that the government does not understand the needs of its inhabitants: namely transparency, free choice and affordable prices."

(Susanne Stulemeyer in Bruzz, 07 March 2014).

\subsubsection{Market Strategy}

The sixth strategy that emerged inductively from the coding process has highlighted the use by Uber of marketing campaigns in 2014 and 2015 to reach out to users. This insight contributes to scholarly work stressing the need to divide institutional work into both market and nonmarket strategies, if we are to better understand a company's political work (e.g., Dorobantu et al. [23]; Uzunca et al. [21]). Actions ranged from fare discounts to free rides offered to users, who greatly responded when taxi services were down due to protest actions held by incumbents. In 2015, Uber also approached the market segment of students by offering bonus discounts to student clubs in Brussels as an alternative to arrangements previously agreed upon with Taxi Verts, a major incumbent taxi company.

"The battle between Uber and the traditional taxi sector is raging fiercely in Brussels. The student market appears to be an important goal in this respect. This is evident from an e-mail to the club of law students at the ULB (Universite Libre de Bruxelles). In the mail, the marketing manager of Uber offers the students a free ride worth 15 euros. Yet, there is also talk of a bonus per ride that the student club would receive in cash."

(Bruzz, 26 March 2015).

\section{Discussion and Conclusions}

In this paper, we addressed two research questions: (1) 'Through which strategies of institutional work does Uber attempt to reshape the institutional context?' and (2) 'How does the city context of Brussels Capital Region contribute to understanding Uber's efforts and (lack of) success in gaining legitimacy?'.

Regarding the first research question, our findings have revealed that as soon as Uber entered the Brussels market in 2014 with UberPOP, the ridesharing company immediately played the role of institutional entrepreneur. Uber used the typical strategies of institutional work, as identified in the theory, though with varying frequencies. While in the first year of operation framing and lobbying were notably the predominant strategies, the situation promptly changed in 2015, as Uber's actions of lobbying began to overtake those of framing. The timeline that we introduced in our study has helped to highlight the ups and downs in Uber's actions of institutional work. It also enabled us to check if strategies followed a logical time order. Our findings showed evidence of intense institutional work by Uber during the first two years of operation in Brussels, followed by low activity in 2016 and 2017. More recently, in 2019 and 2020, the actions of institutional work slightly regained momentum, which coincided with growing protests by the incumbent Brussels taxi industry and court rulings deciding against Uber's practices. According to our findings, Uber's institutional strategies did not follow a specific time order. Consequently, there is no support for the idea (e.g., Battilana et al. [19]; Binz et al. [69]) that institutional entrepreneurs would first tend to focus on strategies aimed at vision sharing (in the form of framing and theorization), before embarking on allocating resources through lobbying, collaboration, negotiation, and, by extension, market strategy. Interestingly, the lack of support for a time order has also featured in recent research on Uber's institutional work in Amsterdam [3]. Future research could examine to what extent this finding is generalizable and fits in the sharing economy logic.

The second research question has been addressed by taking a contingency perspective. Using this perspective, we have generated insights into Uber's strategies in the Brussels 
context. The findings on the seven-year history of Uber's institutional work in Brussels have raised the question whether Uber's strategic efforts have really turned out in its favour. Thus far, Uber's presence in Brussels has not been an unqualified success. The picture is rather one of nuance, showing conflictive forces along with a certain degree of acceptance among users in the market of ridesharing. Similarly to the Amsterdam experience [3], the Brussels launch of UberPOP clearly proved short-lived and a failure of institutional work. The fact that Uber has so far not fully succeeded in radically changing the institutional environment is definitely due to the strong resistance from the incumbent taxi industry and the variating stances taken by local policy makers, who all have their share in these dynamics [85]. Besides, Brussels politics is complex, since power is distributed simultaneously at the European, federal, provincial, city and communal levels [86]. However, the launch of the new services UberX, UberBLACK, and UberVAN that succeeded the UberPOP service has illustrated that even in institutionally complex and strong environments, companies may persevere in seeking lacunas in the system (e.g., the limousine legislation used by Uber as a loophole). Rather than disrupt the institutional playing field in Brussels, Uber mainly focused on keeping a grip on the market by appearing in new guises. During this process, the synergies between Brussels' functions of both the capital of Belgium and hub of EU decision making were not left unused by Uber when it came to mobilizing lobbying efforts. However, to date, a radical change in institutions has not been seen, which feeds the debate about whether Uber is really the disruptive innovator that it is often described to be [44]. More subtle, piecemeal actions may nevertheless also be beneficial for Uber in gaining legitimacy. Future research may look into these alternative tactics.

Our study has implications for sustainability. Uber's explicit articulations on how Brussels could benefit from ridesharing services are an indication that the company is prepared to reach out to city governors to find a common sustainability agenda. Additionally, the findings from the historical analysis have highlighted Uber's alleged commitment to sustainability in environmental, technological, economic and social terms. It is in those terms that the impact of the sharing economy on sustainability has recently been conceptualised and analysed in the literature (e.g., Cohen and Kietzmann [34]; Plepys and Singh [39]; Enochsson et al. [33]). Other studies have identified private car ownership as main cause of negative externalities. Problems of high transport energy usage [87] along with issues of traffic congestion, noise, road damage, and the invasion of public space [88] have proved a challenge to progressing towards environmental sustainability. Additionally, studies on mobility in the urban area of Brussels and regions beyond [89,90] have stressed the need for removing the dominant use of the individual car, in order to reduce social costs in terms of air pollution, noise, accidents, and congestion.

Through tactics of theorization and lobbying, Uber has showed its preparedness to act as a contributor to sustainable mobility systems. The willingness to tackle issues of traffic congestion, parking space and carbon dioxide emission has indicated efforts to meet environmental requirements in favour of sustainable mobility. Since ridesharing may serve as a greener and cheaper alternative to private car use [39], Uber has an obvious role to play in Brussels' plans for sustainable development. Recent studies have highlighted the promising role of concepts such as Mobility-as-a-Service (MaaS), to which ridesharing services may contribute through increased efficiency both for mobility systems and individual users [37]. By combining multi-modal transportation with new ICT and app-based technologies, MaaS may help to redesign future urban mobility [91,92]. The results of recent studies have stressed that ridesharing services such as Uber may play an active role in terms of lower congestion [38], as well as lower travel times and costs due to improved ride matching as part of a multi-modal network [93]. However, the positive effects of ridesharing on energy consumption have been rather undetermined and need further study [92].

Investments in infrastructure for cycling and other transport modes, along with the zero emission target set by 2025 [94], may help to further stimulate technology-based multi-modal transport systems in Brussels [95]. The zero-emission target is, anyhow, a 
major pre-requisite, if we expect Uber to make cities such as Brussels more sustainable. The pre-requisite is important to curb possible adverse effects from the fact that the limousine legislation, under which Uber is operating in Brussels, does not cap the number of cars in circulation [96]. The mobility plan 'Good Move' (2020-2030) of the Brussels Capital Region entails Mobility-as-a-Service as a key component that integrates transport services into digital platforms. In the plan, however, the definition and role of ridesharing services in relation to taxi services need further clarification [97].

By framing itself as a 'technology company' rather than a taxi company, Uber stressed the importance of ICT and apps in ridesharing services. To the extent that technology helps utilize idling resources as part of collaborative consumption [33,34], ridesharing companies such as Uber may help to facilitate sustainable mobility systems. While measuring idle capacity utilization is beyond the scope of the current study, it is worth emphasizing how Uber's rhetoric on this subject has proved accommodative towards Brussels' strategy on low emission mobility [96]. As the strategy stated, the capital of Brussels has involved platform companies such as Uber in initiatives for greener mobility and for a more level playing field. This is a positive evolution, given Brussels' challenging and sometimes conflictive process of decision making, as indicated by the findings. Another interesting element from the findings is that the use of ICT through apps has spilled over to the more traditional, incumbent taxi sector. This illustrates how newcomers such as Uber may revitalise the incumbent sector by introducing technology norms for a more efficient and sustainable taxi market. The use of ICT may also lead to lower fares for users, which is a positive implication for sustainability in economic terms [39]. However, the economic impact may also be negative. First, lower prices may lead to overconsumption of ridesharing services [39,98], and consequently require more capacity and infrastructure up to a level that is not necessarily optimal. Second, if pricing behaviour becomes predatory, new entrants may be kept out of the market. The increased monopoly power that may result from it would be unsustainable due to welfare losses in the market [99]. The creation of a more competitive playing field that harmonises both the innovative ridesharing and more traditional taxi services may help to avoid such problems. The findings from our longitudinal analysis indicated that initially Brussels' efforts in that direction were insufficient. However, in the meantime, Brussels' roadmap for sustainable mobility has stipulated the innovative business models as a key player in the market of taxi rides [96].

In terms of social sustainability, Uber's alleged commitment primarily concerned its contribution to job creation through the employment of drivers. Recent figures have indeed confirmed an increase in Brussels between 2019 and 2021 in the number of Uber cars, from 1200 up to more than 2000 [100]. In addition, as Uber switched from UberPOP to UberX, the company was set to comply with license requirements. However, these efforts tended to contrast with the conflictive situation that culminated in the Court's decision that Uber drivers must be treated as workers rather than as being self-employed. While the decision is beneficial to the incumbent taxi sector, it may also be a sign that ridesharing in Brussels is losing out on its 'gig economy' features, and maturing towards more social protection.

\section{Further Implications and Limitations}

This study also addressed gaps in the literature. The insights on Uber in Brussels have enabled cross-context and cross-case comparison with previous findings on institutional work in the sharing economy. Our findings have revealed similarities (e.g., the factors behind the failure of UberPOP) as well as differences (e.g., the particularly complex governance structure of Brussels deviating from other municipal contexts) with findings in previous research. The longitudinal approach in turn has helped to put institutional strategies in a time perspective. It has become clear that an entrepreneur's institutional work is a dynamic process of ups and downs, that is subject to change over time.

Using the framework of 'coevolution of institutional entrepreneurship' developed by Pacheco et al. [17], and adjusted after testing by Klein Woolthuis et al. [31] and Pelzer et al. [3], has helped to effectively answer our research questions. Holding an integrative 
view, the framework conceptualises the institutional entrepreneur as an actor who, driven by self-interest, wants to change institutions not only to obtain legitimacy, but also to gain economic rent. The contingency perspective that we added to our analysis has shown that context matters if we are to understand the interplay between the institutional entrepreneur and the institutional environment. Consequently, focusing on the local governance level is not at odds with the global market position that companies such as Uber tend to occupy $[8,19,21]$.

Our findings also provided support for the strategy of negotiation, proposed by Klein Woolthuis et al. [31] as an additional key tactic of institutional work, and in line with evidence on Uber in Amsterdam [3], though at a rather low frequency.

The concept of market strategy, that emerged inductively from our data, has given relevance to both market and nonmarket strategies as tactics of institutional work (e.g., Uzunca et al. [21]; Dorobantu et al. [23]). Future research could look further into how these strategies may reinforce institutional change in specific contexts.

From our research, we have learnt that the richness of the existing literature on institutional entrepreneurship comes with a challenge. More specifically, choosing an appropriate theoretical framework needs careful thought and reflection, given the many theoretical lenses drawing from a variety of disciplines (e.g., sociology, management, economics, etc.) [5]. The various empirical applications that recently emerged in the field of institutional entrepreneurship have shown that each theory (e.g., Lawrence and Suddaby [16]; Pacheco et al. [17]) has its merits and limitations. Now that research on institutional entrepreneurship in the sharing economy has reached a more mature stage (e.g., Mair and Reischauer [2]), we motivate scholars to stimulate the debate on the appropriateness of the various theories in relation to the scope and aim of research.

Our findings also provided implications for companies and policy makers by calling for more leadership from both sides. Ridesharing companies such as Uber should realise that contexts of strong regulation and resistance by incumbents, as is the case in Brussels, may turn very conflictive if an innovator is to enter the market. Failing to take into account concerns of local communities may in the end be counterproductive and, not in the least, costly for the (ridesharing) company [101]. Therefore, if Uber wants to achieve long-term embeddedness in the market, it will need to keep the finger on the pulse of the city context, to make sure that the corporate interest and interests of stakeholders are aligned.

For city authorities, such as the Brussels government, we recommend the development of an agenda that addresses more proactively the arrival of innovative business models. Admittedly, policy makers who are to welcome disruptive newcomers should be given time to adapt to the new situation. Especially in the first years of market presence, Uber's operations may tend to overwhelm local governments that are not familiar with new business models [102]. However, the passing of time should leave less room for evasions and urge both Uber and policy makers to take on responsibility. Mutual efforts to seek common agendas should enable key actors to evolve beyond complex decision making and conflicts in the strongly protected taxi market. Brussels' roadmaps and plans for future mobility have confirmed local governors' efforts to involve Uber and other ridesharing companies in future mobility actions [96]. Additionally, other recent studies (e.g., Thelen [22]; Agyemang [26]; Zvolska et al. [36]) have shown how city authorities all too frequently take a reactive approach, paving the way for conflicts, strikes and court rulings, instead of developing vision for the long term. Actions of politicking or rapidly changing policy priorities will do little to turn the tide. Additionally, the practice by city authorities of invoking moral arguments, as appeared from our findings, risks ending up in deadlocks, especially when the focus remains on countering the innovative newcomer. If city authorities are to build pathways to sustainable smart cities [29], then the moral argument may prove more effective when it is primarily used for long term vision and commitment on sustainable mobility. Keeping a focus on sustainability is more likely to be successful in creating a playing field that is beneficial to the broader society. 
Our study has some limitations. First, our sample may suffer from bias, a common limitation of press text analysis. What we know about Uber's institutional strategies is based on what was reported in the press. However, even high-quality journalism is not free from possible bias, due to nudging techniques being used for commercial purposes. This bias may eventually reflect on the amount and quality of the news reporting. Challenges to measure lobbying, an often hidden activity [58,63,65], may further reinforce the bias. Of all institutional strategies, lobbying is the most sensitive and therefore more likely to be underreported in the analysis, despite regular media coverage. Lobbying contrasts with strategies of framing and theorization, which particularly thrive on (media) communication. The strategy also differs from collaboration, negotiation, and market strategies, which are typically more public. To keep a consistent methodology lens, we preferred, however, to measure all strategies using the same type of data collection based on content analysis. Future research could further explore lobbying actions in ridesharing, by using alternative measures.

Second, there is a caveat to the occurrence-based approach of the content analysis. The low frequency that characterizes some tactics raises questions regarding representativeness. Even the higher frequencies should be interpreted with caution, given the non-randomized, purposive sample that is used. The quantitative part of the results should therefore be seen as illustrative to the more comprehensive qualitative part of the analysis. Especially the latter has contributed to understanding Uber's institutional work in the Brussels context, in relation to other actors in the playing field.

Third, in mapping out the nonmarket and market institutional strategies, the question has remained as through which process strategies tend to translate into legitimacy seeking and, eventually, institutional change. Further insight into this process may be gathered through interviews that contrast and compare views of managerial decision makers in the sharing economy with views of local policy makers.

Supplementary Materials: The following are available online at https:/ / www.mdpi.com/article / $10.3390 /$ su13148037/s1.

Author Contributions: Conceptualization, M.D. and I.S.; methodology, I.S.; software, M.D.; validation, M.D. and I.S.; formal analysis, M.D. and I.S.; investigation, M.D. and I.S.; writing—original draft preparation, M.D. and I.S.; writing-review and editing, I.S.; visualization, M.D.; supervision, I.S. All authors have read and agreed to the published version of the manuscript.

Funding: This research received no external funding.

Institutional Review Board Statement: Not applicable.

Informed Consent Statement: Not applicable.

Data Availability Statement: Data are contained within the article or Supplementary Materials. The data presented in this study are available upon request via the editors.

Acknowledgments: We gratefully acknowledge participants in the 7th 'Sharing Cultures: International Workshop on the Sharing Economy', Barcelona virtual event (24-26 February 2021) for their valuable comments.

Conflicts of Interest: The authors declare no conflict of interest.

\section{References}

1. Martin, C.J. The sharing economy: A pathway to sustainability or a nightmarish form of neoliberal capitalism? Ecol. Econ. 2016, 121, 149-159. [CrossRef]

2. Mair, J.; Reischauer, G. Capturing the dynamics of the sharing economy: Institutional research on the plural forms and practices of sharing economy organizations. Technol. Forecast. Soc. Chang. 2017, 125, 11-20. [CrossRef]

3. Pelzer, P.; Frenken, K.; Boon, W. Institutional entrepreneurship in the platform economy: How Uber tried (and failed) to change the Dutch taxi law. Environ. Innov. Soc. Transit. 2019, 33, 1-12. [CrossRef]

4. Zvolska, L.; Voytenko Palgan, Y.; Mont, O. How do sharing organisations create and disrupt institutions? Towards a framework for institutional work in the sharing economy. J. Clean. Prod. 2019, 219, 667-676. [CrossRef] 
5. Acquier, A.; Carbone, V.; Vasseur, L. The sharing economy as an emerging and contested field—How classic and institutional entrepreneurs cope with plural theoretical frames. Res. Sociol. Oranizations 2020, 66, 107-129. [CrossRef]

6. Curtis, S.K.; Lehner, M. Defining the sharing economy for sustainability. Sustainability 2019, 11, 567. [CrossRef]

7. Frenken, K.; Schor, J. Putting the sharing economy into perspective. Environ. Innov. Soc. Transit. 2017, 23, 3-10. [CrossRef]

8. Parente, R.C.; Geleilate, J.M.G.; Rong, K. The sharing economy globalization phenomenon: A research agenda. J. Int. Manag. 2018, 24, 52-64. [CrossRef]

9. Täuscher, K.; Laudien, S.M. Understanding platform business models: A mixed methods study of marketplaces. Eur. Manag. J. 2018, 36, 319-329. [CrossRef]

10. Zhang, C. China's new regulatory regime tailored for the sharing economy: The case of Uber under Chinese local government regulation in comparison to the EU, US, and the UK. Comput. Law Secur. Rev. 2019, 35, 462-475. [CrossRef]

11. Willis, G.; Tranos, E. Using 'big data' to understand the impacts of Uber on taxis in New York City. Travel Behav. Soc. 2021, 22, 94-107. [CrossRef]

12. Gonzalez-Padron, T.L. Ethics in the sharing economy: Creating a legitimate marketing channel. J. Mark. Channels 2017, 24, 84-96. [CrossRef]

13. Lesteven, G.; Godillon, S. Fuelling the controversy on Uber's arrival: A comparative media analysis of Paris and Montreal. Cities 2020, 106, 102864. [CrossRef]

14. Greenwood, R.; Suddaby, R.; Hinings, C.R. Theorizing change: The role of professional associations in the transformation of institutionalized fields. Acad. Manag. J. 2002, 45, 58-80. [CrossRef]

15. Lawrence, T.B.; Leca, B.; Zilber, T.B. Institutional work: Current research, new directions and overlooked issues. Organ. Stud. 2013, 34, 1023-1033. [CrossRef]

16. Lawrence, T.B.; Suddaby, R. Institutions and institutional work. In Handbook of Organization Studies; Clegg, S.R., Hardy, C., Lawrence, T.B., Nord, W.R., Eds.; Sage: London, UK, 2006; pp. 215-254.

17. Pacheco, D.F.; York, J.G.; Dean, T.J.; Sarasvathy, S.D. The coevolution of institutional entrepreneurship: A tale of two theories. J. Manag. 2010, 36, 974-1010. [CrossRef]

18. Suddaby, R.; Elsbach, K.D.; Greenwood, R.; Meyer, J.W.; Zilber, T.B. Organizations and their institutional environments-Bringing meaning, values, and culture back in: Introduction to the special research forum. Acad. Manag. J. 2010, 53, 1234-1240. [CrossRef]

19. Battilana, J.; Leca, B.; Boxenbaum, E. 2 How actors change institutions: Towards a theory of institutional entrepreneurship. Acad. Manag. Ann. 2009, 3, 65-107. [CrossRef]

20. Boon, W.P.C.; Spruit, K.; Frenken, K. Collective institutional work: The case of Airbnb in Amsterdam, London and New York. Ind. Innov. 2019, 26, 898-919. [CrossRef]

21. Uzunca, B.; Rigtering, J.P.C.; Ozcan, P. Sharing and shaping: A cross-country comparison of how sharing economy firms shape their institutional environment to gain legitimacy. Acad. Manag. Discov. 2018, 4, 248-272. [CrossRef]

22. Thelen, K. Regulating Uber: The politics of the platform economy in Europe and the United States. Perspect. Polit. 2018, 16, 938-953. [CrossRef]

23. Dorobantu, S.; Kaul, A.; Zelner, B. Nonmarket strategy research through the lens of new institutional economics: An integrative review and future directions. Strateg. Manag. J. 2017, 38, 114-140. [CrossRef]

24. Marquis, C.; Battilana, J. Acting globally but thinking locally? The enduring influence of local communities on organizations. Res. Organ. Behav. 2009, 29, 283-302. [CrossRef]

25. Mohamed, M.J.; Rye, T.; Fonzone, A. Operational and policy implications of ridesourcing services: A case of Uber in London, UK. Case Stud. Transp. Policy 2019, 7, 823-836. [CrossRef]

26. Agyemang, E. "Uber is here to stay": Exploring the policy implications of the Uber-Local taxis turf war in Accra, Ghana. Case Stud. Transp. Policy 2020, 8, 59-66. [CrossRef]

27. Gurses, K.; Ozcan, P. Entrepreneurship in regulated markets: Framing contests and collective action to introduce pay TV in the U.S. Acad. Manag. J. 2015, 58, 1709-1739. [CrossRef]

28. Battilana, J.; D'Aunno, T. Institutional work and the paradox of embedded agency. In Institutional Work: Actors and Agency in Institutional Studies of Organizations; Cambridge University Press: Cambridge, UK, 2009; pp. 31-58, ISBN 9780511596605.

29. Akande, A.; Cabral, P.; Casteleyn, S. Understanding the sharing economy and its implication on sustainability in smart cities. J. Clean. Prod. 2020, 277, 124077. [CrossRef]

30. Vaskelainen, T.; Münzel, K. The effect of institutional logics on business model development in the sharing economy: The case of German carsharing services. Acad. Manag. Discov. 2018, 4, 273-293. [CrossRef]

31. Klein Woolthuis, R.; Hooimeijer, F.; Bossink, B.; Mulder, G.; Brouwer, J. Institutional entrepreneurship in sustainable urban development: Dutch successes as inspiration for transformation. J. Clean. Prod. 2013, 50, 91-100. [CrossRef]

32. Baron, D.P. Integrated strategy: Market and nonmarket strategies. Calif. Manag. Rev. 1995, 37, 47-65. [CrossRef]

33. Enochsson, L.; Palgan, Y.V.; Plepys, A.; Mont, O. Impacts of the sharing economy on urban sustainability: The perceptions of municipal governments and sharing organisations. Sustainability 2021, 13, 4213. [CrossRef]

34. Cohen, B.; Kietzmann, J. Ride on! Mobility business models for the sharing economy. Organ. Environ. 2014, 27, 279-296. [CrossRef]

35. Gao, P.; Li, J. Understanding sustainable business model: A framework and a case study of the bike-sharing industry. J. Clean. Prod. 2020, 267. [CrossRef] 
36. Zvolska, L.; Lehner, M.; Voytenko Palgan, Y.; Mont, O.; Plepys, A. Urban sharing in smart cities: The cases of Berlin and London. Local Environ. 2019, 24, 628-645. [CrossRef]

37. Jittrapirom, P.; Caiati, V.; Feneri, A.M.; Ebrahimigharehbaghi, S.; Alonso-González, M.J.; Narayan, J. Mobility as a service: A critical review of definitions, assessments of schemes, and key challenges. Urban Plan. 2017, 2, 13-25. [CrossRef]

38. Narayanan, S.; Chaniotakis, E.; Antoniou, C. Shared autonomous vehicle services: A comprehensive review. Transp. Res. Part C Emerg. Technol. 2020, 111, 255-293. [CrossRef]

39. Plepys, A.; Singh, J. Evaluating the sustainability impacts of the sharing economy using input-output analysis. In $A$ Research Agenda for Sustainable Consumption Governance; Mont, O., Ed.; Edward Elgar Publishing: Cheltenham, UK, 2019; pp. 66-84, ISBN 9781788117814.

40. Fligstein, N. Markets as politics: A political-cultural approach to market institutions. Am. Sociol. Rev. 1996, 61, 656-673. [CrossRef]

41. Aldrich, H.E.; Fiol, C.M. Fools rush in? The institutional context of industry creation. Acad. Manag. Rev. 1994, 19, 645-670. [CrossRef]

42. DiMaggio, P.J.; Powell, W.W. The iron cage revisited: Institutional isomorphism and collective rationality in organizational fields. Am. Sociol. Rev. 1983, 48, 147-160. [CrossRef]

43. Levy, D.; Scully, M. The institutional entrepreneur as modern prince: The strategic face of power in contested fields. Organ. Stud. 2007, 28, 971-991. [CrossRef]

44. Christensen, C.M.; Raynor, M.; McdDonald, R. What is distruptive innovation? Harv. Bus. Rev. 2015, 93, 44-53.

45. Hillman, A.J.; Hitt, M.A. Corporate political strategy formulation: A model of approach, participation, and strategy decisions. Acad. Manag. Rev. 1999, 24, 825-842. [CrossRef]

46. Marquis, C.; Raynard, M. Institutional strategies in emerging markets. Acad. Manag. Ann. 2015, 9, 291-335. [CrossRef]

47. Hong, S.; Lee, S. Adaptive governance, status quo bias, and political competition: Why the sharing economy is welcome in some cities but not in others. Gov. Inf. Q. 2018, 35, 283-290. [CrossRef]

48. Hong, S.; Lee, S. Adaptive governance and decentralization: Evidence from regulation of the sharing economy in multi-level governance. Gov. Inf. Q. 2018, 35, 299-305. [CrossRef]

49. Anderson, T.L.; Hill, P.J. Cowboys and contracts. J. Legal Stud. 2002, 31, S489-S514. [CrossRef]

50. Scott, S.; Venkataraman, S. The promise of entrepreneurship as a field of research. Acad. Manag. Rev. 2000, 25, $217-226$.

51. Greenwood, R.; Suddaby, R. Institutional entrepreneurship in mature fields: The big five accounting firms. Acad. Manag. J. 2006, 49, 27-48. [CrossRef]

52. Frenken, K.; Fuenfschilling, L. The rise of online platforms and the triumph of the corporation. Sociologica 2020, 14, 101-113.

53. Frenken, K.; Vaskelainen, T.; Fünfschilling, L.; Piscicelli, L. An institutional logics perspective on the gig economy. In Theorizing the Sharing Economy: Variety and Trajectories of New Forms of Organizing Research in the Sociology of Organizations; Maurer, I., Mair, J., Oberg, A., Eds.; Emerald Publishing Limited: Bingley, UK, 2020; Volume 66, pp. 83-105.

54. Benford, R.D.; Snow, D.A. Framing processes and social movements: An overview and assessment. Annu. Rev. Sociol. 2000, 26, 611-639. [CrossRef]

55. Fligstein, N. Social skill and institutional theory. Am. Behav. Sci. 1997, 40, 397-405. [CrossRef]

56. Misangyi, V.F.; Weaver, G.R.; Elms, H. Ending corruption: The interplay among institutional logics, resources, and institutional entrepreneurs. Acad. Manag. Rev. 2008, 33, 750-770. [CrossRef]

57. Orsato, R.J.; den Hond, F.; Clegg, S.R. The political ecology of automobile recycling in Europe. Organ. Stud. 2002, 23, 639-665. [CrossRef]

58. Van Doorn, N. A new institution on the block: On platform urbanism and Airbnb citizenship. New Media Soc. 2020, 22, 1808-1826. [CrossRef]

59. Walker, E.T.; Rea, C.M. The political mobilization of firms and industries. Annu. Rev. Sociol. 2014, 40, 281-304. [CrossRef]

60. Strang, D.; Meyer, J.W. Institutional conditions for diffusion. Theory Soc. 1993, 22, 487-511. [CrossRef]

61. Mellahi, K.; Frynas, J.G.; Sun, P.; Siegel, D. A review of the nonmarket strategy literature: Toward a multi-theoretical integration. J. Manage. 2016, 42, 143-173. [CrossRef]

62. Gökgöz, M.; Gökgöz, F. Analyzing lobbying entities of Brussels operational in research, technological development and innovation domain. Int. J. Econ. Perspect. 2017, 11, 5-17.

63. Anastasiadis, S. Toward a view of citizenship and lobbying: Corporate engagement in the political process. Bus. Soc. 2014, 53, 260-299. [CrossRef]

64. Hillman, A.J.; Keim, G.D.; Schuler, D. Corporate political activity: A review and research agenda. J. Manag. 2004, 30, 837-857. [CrossRef]

65. Chen, H.; Parsley, D.; Yang, Y.W. Corporate lobbying and firm performance. J. Bus. Financ. Account. 2015, 42, 444-481. [CrossRef]

66. Wijen, F.; Ansari, S. Overcoming inaction through collective institutional entrepreneurship: Insights from regime theory. Organ. Sci. 2007, 28, 1079-1100. [CrossRef]

67. Lawrence, T.B.; Hardy, C.; Phillips, N. Institutional effects of interorganizational collaboration: The emergence of proto-institutions. Acad. Manag. J. 2002, 45, 281-290. [CrossRef]

68. Garud, R.; Sanjay, J.; Kumaraswamy, A. Institutional entrepeneurship in the sponsorship of common technological standards: The case of Sun Microsystems and Java. Acad. Manag. J. 2002, 45, 196-214. 
69. Binz, C.; Harris-Lovett, S.; Kiparsky, M.; Sedlak, D.L.; Truffer, B. The thorny road to technology legitimation-Institutional work for potable water reuse in California. Technol. Forecast. Soc. Chang. 2016, 103, 249-263. [CrossRef]

70. Bryman, A. Social Research Methods, 4th ed.; Oxford University Press: Oxford, UK, 2012.

71. Blumberg, B.; Cooper, D.R.; Schindler, P.S. Business Research Methods, 4th ed.; McGraw-Hill Education: Berkshire, London, UK, 2014.

72. Carley, K. Coding choices for textual analysis: A comparison of content analysis and map analysis. Sociol. Methodol. 1993, 23, 75-126. [CrossRef]

73. Hsieh, H.; Shannon, S.E.; Shannon, S.E. Three approaches to qualitative content analysis. Qual. Health Res. 2005, 15, 1277-1288. [CrossRef]

74. Kohlbacher, F. The use of qualitative content analysis in case study research. Forum Qual. Sozialforsch./Forum Qual. Soc. Res. 2006, 7, 1-30.

75. Sekaran, U.; Bougie, R. Research Methods for Business: A Skill Building Approach, 7th ed.; Wiley: Hoboken, NJ, USA, 2016.

76. Krippendorff, K. Content analysis. Int. Encycl. Commun. 1989, 1, 403-407.

77. Glaser, B.G.; Strauss, A. The Discovery of Grounded Theory: Strategies for Qualitative Research; Sociology Press: Mill Valley, CA, USA, 1967.

78. Erlingsson, C.; Brysiewicz, P. A hands-on guide to doing content analysis. Afr. J. Emerg. Med. 2017, 7, 93-99. [CrossRef]

79. Flyvbjerg, B. Five misunderstandings about case-study research. Qual. Inq. 2006, 12, 219-245. [CrossRef]

80. LeCompte, M.D.; Goetz, J.P. Problems of reliability and validity in ethnographic research. Rev. Educ. Res. 1982, 52, 31-60. [CrossRef]

81. Lombard, M.; Snyder-duch, J.; Bracken, C.C. Content analysis in mass communication: Assessment and reporting of intercoder reliability. Hum. Commun. Res. 2002, 28, 587-604. [CrossRef]

82. Hodson, R. Analyzing Documentary Accounts; Sage: Thousand Oaks, CA, USA, 1999.

83. Krippendorff, K. Reliability in content analysis: Some common misconceptions and recommendations. Hum. Commun. Res. 2004, 30, 411-433. [CrossRef]

84. Blind, K. The influence of regulations on innovation: A quantitative assessment for OECD countries. Res. Policy 2012, 41, 391-400. [CrossRef]

85. Greenwood, R.; Hinings, C.R. Understanding radical organizational change: Bringing together the old and the new institutionalism. Acad. Manag. Rev. 1996, 21, 1022-1054. [CrossRef]

86. Bousetta, H.; Favell, A.; Martiniello, M. Governing multicultural Brussels: Paradoxes of a multi-level, multi-cultural, multinational urban anomaly. J. Ethn. Migr. Stud. 2018, 44, 2070-2085. [CrossRef]

87. Dingil, A.E.; Schweizer, J.; Rupi, F.; Stasiskiene, Z. Updated models of passenger transport related energy consumption of urban areas. Sustainability 2019, 11, 4060. [CrossRef]

88. Chatziioannou, I.; Alvarez-Icaza, L.; Bakogiannis, E.; Kyriakidis, C.; Chias-Becerril, L. A structural analysis for the categorization of the negative externalities of transport and the hierarchical organization of sustainable mobility's strategies. Sustainability 2020, 12, 6011. [CrossRef]

89. Hubert, M.; Lebrun, K.; Huynen, P.; Dobruszkes, F. Daily mobility in Brussels: Challenges, tools and priority undertakings. Brussels Stud. 2013. [CrossRef]

90. De Clerck, Q.; van Lier, T.; Messagie, M.; Macharis, C.; Van Mierlo, J.; Vanhaverbeke, L. Total cost for society: A persona-based analysis of electric and conventional vehicles. Transp. Res. Part D Transp. Environ. 2018, 64, 90-110. [CrossRef]

91. Goetz, A.R. Transport challenges in rapidly growing cities: Is there a magic bullet? Transp. Rev. 2019, 39, 701-705. [CrossRef]

92. Becker, H.; Balac, M.; Ciari, F.; Axhausen, K.W. Assessing the welfare impacts of shared mobility and mobility as a service (MaaS). Transp. Res. Part A 2020, 131, 228-243. [CrossRef]

93. Nazari, F.; Noruzoliaee, M.; Mohammadian, A. Shared versus private mobility: Modeling public interest in autonomous vehicles accounting for latent attitudes. Transp. Res. Part C Emerg. Technol. 2018, 97, 456-477. [CrossRef]

94. City of Brussels. Sustainable Development. Available online: https://www.brussels.be/sustainable-development (accessed on 2 July 2021).

95. Brussel Mobiliteit. De Fiets en Het Openbaar Vervoer. Available online: https://mobilite-mobiliteit.brussels/nl/zich-verplaatsen/ fiets/kies-uw-traject/intermodaliteit (accessed on 2 July 2021).

96. Leefmilieu Brussels. Strategie 'Low Emission Mobility'. Available online: https://leefmilieu.brussels/themas/mobiliteit/ strategie-low-emission-mobility (accessed on 2 July 2021).

97. Brussels Mobility. Good Service. Available online: https://mobilite-mobiliteit.brussels/en/good-move/good-service (accessed on 8 July 2021).

98. McCormick, K.; Neij, L.; Mont, O.; Ryan, C.; Rodhe, H.; Orsato, R. Advancing sustainable solutions: An interdisciplinary and collaborative research agenda. J. Clean. Prod. 2016, 123, 1-4. [CrossRef]

99. Katz, V. Regulating the sharing economy. Berkeley Technol. Law J. 2016, 30, 1067-1126. [CrossRef]

100. Zimmerman, A.; Cokelaere, H.; Posaner, J. Brussels bans Uber Drivers from Picking Up Rides through the App. Available online: https:/ / www.politico.eu/article/brussels-bans-uber-drivers-from-picking-up-rides-through-the-app/ (accessed on 5 July 2021). 
101. Dorobantu, S.; Flemming, D. It's Never Been More Important for Big Companies to Listen to Local Communities. Available online: https:/ / hbr.org/2017/11/its-never-been-more-important-for-big-companies-to-listen-to-local-communities (accessed on 17 May 2021).

102. Cannon, S.; Summers, L.H. How Uber and the Sharing Economy Can Win over Regulators. Available online: https://hbr.org/20 14/10/how-uber-and-the-sharing-economy-can-win-over-regulators (accessed on 30 June 2021). 